sciendo

10.2478/abcsj-2020-0021

\title{
Transgression and Empowerment in Sarah Hall's Short Fiction
}

\author{
ANA RAQUEL FERNANDES \\ Universidade Europeia, Lisbon, \\ ULICES - University of Lisbon Centre for English Studies, Portugal
}

\begin{abstract}
This essay delivers an analysis of the innovative short fiction of contemporary British writer Sarah Hall. It gives particular consideration to the first two collections of short stories published by the author, The Beautiful Indifference (2011) and Madame Zero (2017), as well as looking into the possibilities offered by her latest collection, Sudden Traveler (2019). Hall focuses attention on such varied contemporary preoccupations as identity, gender, violence and death. My goal is to discuss the way that identities are subverted or transgressed in her short stories and how the topic of identity representation intersects with other themes becoming a fundamental and empowering factor in the narrative structure. Hall's short story collections present an interesting case study, not only because they display the writer's quest for a unity of subjectmatter, but also because they evince the strength and vitality of the short story as a genre.
\end{abstract}

Keywords: Sarah Hall, contemporary short fiction, identity, transgression, empowerment

\section{Introduction: Sarah Hall and the Short Story}

In her introduction to Re-Reading the Short Story, Clare Hanson suggests that '[f]or a complex of reasons the short story has been largely excluded from the arena of critical debate' (1). Hanson identifies the failure to discuss this genre as a 'paradoxical situation' (1). She pinpoints three main reasons why, despite its popularity, the short story has continuously 
been stripped of its worth for contemporary critical debate: firstly, lack of respectability as an art form because it is considered to be popular in a pejorative sense; secondly, inferiority because its genesis is linked to women authors writing in weekly magazines; and finally, because, since magazines are volatile and ephemeral by nature, short stories eventually cease to be published, and, with the passage of time, texts become increasingly difficult to access.

Hanson's edited essay volume dates from the end of the 1980s, and in the new millennium circumstances have visibly changed. Evidence of this new situation can be found, for instance, in mainstream prizes awarded to short story writers - Alice Munro winning the 2013 Nobel Prize in Literature being the best example. Evidence can also be found in the rise of short-story specific prizes, examples of which are the BBC National Short Story Award (launched in 2005 at the Edinburgh International Book Festival); the Costa Short Story Award (launched in 2012) and the Harper's Bazaar Short Story (launched in 2014). Indeed, prizes are an influential way of bringing writers and genres to the attention of readers, as Sam Baker reminds us in the article "The Irresistible Rise of the Short Story" (The Telegraph). In addition to discussing the important role literary prizes play in the rise of the genre, Baker also tackles three other relevant questions. Firstly, the role of technology and digital publishing in helping to disseminate the short story (e.g. Ether Books launched at the London International Book Fair 2010). Secondly, the importance of mainly American magazines which take the genre seriously and routinely publish short fiction (well-known examples being The New Yorker and The Paris Review). Thirdly, the growth of the Creative Writing education industry in America, in particular, but also, as is increasingly noticeable in the UK, the launch of creative writing programmes in universities (the University of East Anglia pioneered the teaching of creative writing in the UK) and beyond - novelist Ann Davies launched the Curtis Brown Agency, the first agency-led writing school in 2011. As Ailsa Cox argues, "[o]n both sides of the Atlantic, short story writers are proliferating, often under the auspices of creative writing programmes" (ix). ${ }^{i}$ And Emma Young attributes the growth of the short story to the increasing numbers of women short-story writers, suggesting 
that the formal features of the genre allow for "a wider engagement with feminist politics" (1).

In the contemporary British literary scene, Sarah Hall's interest in the short story attests to Young's argument, with evidence found in the three collections of short stories published by the author: The Beautiful Indifference (2011), Madame Zero (2017) and Sudden Traveler (2019). ${ }^{\mathrm{ii}}$ According to Young, "it is clear that the multi-vocal and polyphonic nature of the short story collection itself offers great potential for $[\ldots]$ women writers as they seek to explore the ontological realities of gender and sexual politics in the most diverse ways" (154). Hall effectively exploits this element of the form, together with "the ambiguous potential cultivated by brevity" (Young 144).

Yet this engagement with the formal possibilities of the form might be for naught if Hall were not so adept at negotiating the cultural field of short story publication. One could argue with Hanson that the negative side of the dispersed range of publication venues is the invisibility of short fiction, since the fact that it is published in perishable media makes it hard to keep track of what has been or is published on a daily basis. However, many of Hall's short stories have been shortlisted for Short Story Awards, making their original place of publication - unlike many other examples of the form - easily traceable. As far as the first collection of short stories is concerned, "Butcher's Perfume" was shortlisted for the BBC National Short Story Award 2010 and "Vuotjärvi" was long-listed for the Sunday Times EFG Private Bank Short Story Award 2011. Regarding the second collection of short stories, Madame Zero, "Evie" was shortlisted for the Sunday Times EFG Private Bank Short Story Award 2013. Other stories have been awarded prizes, as is the case of "Mrs Fox," which won the BBC National Short Story Prize 2013. And both collections themselves won prizes: The Beautiful Indifference won the Portico Prize for Fiction, in 2012, and the Edge Hill Short Story Prize; and Madame Zero was shortlisted for the Edge Hill Short Story Prize 2018. iii This pattern is recurrent as far as Hall's short fiction track record is concerned and quite exceptional, taking into account not only the various prizes for individual stories but also for the short-story collections. As recently as 2018, the short story "Sudden Traveler" became the second contender for the BBC 
National Short Story Award, while her short story "Later, His Ghost" (from the collection Madame Zero) was included in The Penguin Book of the Contemporary British Short Story in the same year. ${ }^{\text {iv }}$ Regarding the volume, editor Philip Hensher explains that: "This is an attempt to survey the best British short-story writers of the last twenty years, and to suggest what the short story still does well" (ix). In his introduction, Hensher is quite critical of literary competition, although he argues that "[1]iterary competitions are [...] mostly harmless if they form part of a healthy ecology" (xii). In his view, nowadays it is increasingly the case that "[a] story is written to satisfy the strictures of a judging panel [...] Readers have been replaced by patrons [...] and the results are unappealing" (xii). Nevertheless, there are exceptions, and Hall is an accomplished example. When discussing Hall's "Later, His Ghost," Hensher makes the following observation, which testifies to the way Hall negotiates the cultural field of short story publication:

Sarah Hall is an expert writer whose expertise has been clearly formed by a serious engagement with creative writing courses. This story ["Later, His Ghost"] is perhaps the most conventional in the book [...]. But the story possesses its own energy [...]. There are plenty of bad writers in Hall's vein: she is a very good writer, working within publicly accepted conventions. (xx)

Hall's literary work, in particular her short stories, are notable examples of the relationship between the material conditions of production, circulation and consumption of literature and culture nowadays (see Bourdieu 1993). Indeed, literary awards for short fiction are very much 'events' in the cultural scene, attracting public attention. Moreover, the fact that the BBC prize shortlisted stories are broadcast on the radio (BBC Radio 4) and eventually become podcasts heightens the idea of the 'literary events' they are. The awards, which garner a considerable amount of transient attention, together with the dissemination strategies of the short stories via radio and podcasts are a means for boosting Hall's literary career and help her to achieve greater prominence as a writer. 


\section{The Event in Sarah Hall's Short Fiction}

Throughout the body of the short stories in the first two collections, which will be my main focus of attention, one concept in particular emerges as meaningful: that of the event. From the Latin êventus, and understood as "something that happens or takes place, esp. something significant or noteworthy; an incident, an occurrence" (Oxford English Dictionary), the event occurs in all of Hall's short stories, and it becomes the condition for the narrative to unfold. Indeed, events allow us to grasp what seems to be indescribable, beyond words. As Roberto Casati and Achille Varzi argue, "events are said to occur or happen or take place [...]; events tolerate colocation [...]; events are occurrents - they take up time and persist by having different parts (or "stages") at different times" (n. pag.). In Hall's short stories, events are crucial in the narrative, they are dynamic, displaying vague spatial boundaries and crisp temporal limits as becomes evident in the discussion of the short stories selected, in particular if one links each event to the surrounding (natural) space depicted in the narrative. Nevertheless, events may occur differently in Hall's short stories. Often they involve grasping the precariousness of human life, as many of the short stories from Madame Zero discussed below make manifest ("Wilderness," "Goodnight nobody," and "Later, His Ghost"). Often the event in Hall's work is linked to an occurrence involving an animal, reminding readers of the inseparability of both human and animal life as for instance is the case with the short stories from Hall's first collection. In "Butcher's Perfume," there is a turning point when Kathleen, the first-person narrator, discovers a horse in the foulest of conditions on a dilapidated farm somewhere in Cumbria. The "Perfume" in the title represents the stench of death and disease on the farm:

A dead horse was lying on the ground [...] The ground was slick yellowbrown, like concrete covered in piss and diarrhoea. I stepped closer, in under the gable, and a stink rose. [...] I took another step in and the horse snorted and moved [...] It snorted out a pink foam that was lathered in its nostrils, and dragged its back legs again. Click-click. Then it was still. (Hall, The Beautiful Indifference 29-30) 
Illness and death are ongoing themes in Hall's writing. Nevertheless, in "Butcher's Perfume" the event of coming by chance on the dying horse is a reminder that animals and humans are bound together. The horse was neglected by the farmer and deliberately ill-treated. The narrative, however, evinces how the destinies of both humans and animals may be closer than anticipated. The 'ratchety farmer' is firmly punished by the Slessors, the family that fascinates Kathleen because of their unconventionality and closeness to the natural world: "they've been forged from the old rage of the north [...]. They came from gipsy stock, scrappies, dog- and horse-breeders, fire-mongers" (Hall, The Beautiful Indifference, 4). The farmer's violent end matches the one he inflicted on the horse: "They'd strung him up in the shed by his feet and cut the bastard with a riding crop right through to the putty in his spine. He was in Newcastle Infirmary [...] not expected to walk again" (36).

In the short story "The Beautiful Indifference" there is a striking episode with a horse that goes astray. The event of the straying horse sets up a parallel between the horse trying to break free and the female main character, an unmarried 'country girl' who is waiting for her lover in a room at a hotel and who does not follow social conventions. Indeed, the main character's apparent denial of 'the natural order of things' is manifest in her friends' reactions, demonstrating the volatile disposition of society. The narrator tries to make sense of the strong bias against liberated (older) women:

She had noticed a change in the way her female friends responded to the relationship lately. At first they'd been enthusiastic [...] But as the relationship had taken hold, becoming less casual, notes of disapproval had entered the discussion $[\ldots]$ Perhaps she did seem ridiculous to them [...] Perhaps she was not entitled to the sex after all [...] Men, on the other hand, had been unnerved from the beginning, as if she was not keeping to the natural order of things, as if she was performing an inversion. Or they had commented how lucky her lover was, recalling fondly an affair they themselves had had with an older woman during their youth. (Hall, The Beautiful Indifference 44-45)

Young examines how contemporary women short-story writers continually engage with the topic of women's sexuality. In particular, Young focuses on Hall's short story "The Beautiful Indifference" in order 
to examine "sexuality as a site of political resistance for women" (117). The narrative device of two friends conversing - a flash back of the main character while waiting for her lover - highlights "the ways in which sexuality, sexual identity and behaviour are mediated by the expectations and 'norms' of society and culture" (Young 120). Moreover, Young suggests that " $[t]$ he indifference projected by the narrator's friends reflects the sentiment of judgement inherent in their responses, while the protagonist's indifference to societal expectations contains a beautiful resonance of its own" (121). The main character's transgressive behaviour empowers her and allows for a political commentary, a critique on common notions of womanhood and normative behaviour, disrupting "the linear tendencies which suggest that at a particular age a woman's sexual relationship or her social responsibilities should be of a certain makeup" (Young 121), i.e. defined by motherhood and/or women's domestic roles. The excerpt from the short story quoted above foregrounds the cultural assumptions that marriage or a permanent relationship with a man naturally leading to motherhood and domesticity - is proof of adulthood (see Letherby 1994). The main character's transgressive behaviour challenges the (mis)representation of women's identity and of the concept of womanhood understood as single and unique, offering instead a more complex approach to the experience of being a woman.

Since the main character's behaviour is perceived by others as undesirable or out of the right way, it is perhaps only natural to identify a distinct parallel between the non-conventional female character and the straying horse, her conduct and his:

The driver was calling to the horse, whoa, whoa, in a tone of irrefutable stewardship, but something was wrong [...] The shire kicked away, its reins trailing, its eye white cupped and livid. It passed her at the exact moment she thought about stepping out with her arms held up. She felt its wake. (Hall, The Beautiful Indifference 61, my emphasis)

The last sentence of the description - "She felt its wake" - becomes particularly significant to grasp the overall meaning of the short story. It is as if watching and feeling empathy for the horse rouses her from her apparent dawdling. Just as the horse breaks free from the driver's control, 
so the main character seems to break free from societal expectations and the pressure exerted on the (female) individual. Away from the city, her lover and the public eye, in the Pennines, the main character can be herself. Indeed, the natural world exists beyond human beings or civilization. Moreover, nature is depicted as having the ability to regenerate: "She drove back across the Pennines. On the moorland the bracken was beginning to regenerate" (Hall, The Beautiful Indifference 64). Conversely, the decay of the human body is made plain in the comparison of life erupting again from dead twigs and abnormal cells that invade or spread in the human body: "Tight green spirals were coming up through the sea of dead stalks. The curled fronds looked ovarian. Like the illustration of these organs they had shown her to explain" (64). Furthermore, the recollection of her mother's suicide and the parallel between the two, as well as the creeping topic of immanent illness and death, appear to be in opposition to what is perceived as the natural order of life: "In her purse were the white boxes. After she had left the train station she had bought three packets of painkillers, from different pharmacies. It had been easy. Her mother had been the same age' (65). The beautiful indifference is also evocative of the overwhelming essence of nature, lasting in all its beauty despite the main character's feebleness and eventual decay.

In "Bees," also from The Beautiful Indifference, the event is equally crucial for the unfolding of the narrative. The short story starts with an unsolved mystery - dead bees in a little private garden in London - and ends with the surprising appearance of a fox, which solves the mystery. The narrator addresses a second person, a newcomer to the city of London, a woman from the North who is attempting to rebuild her life after years of domestic violence, abuse and a broken relationship as the reader soon learns: "You've come to forget, to move on. And with this move, some lurid internal part of you has unzipped your flesh and stepped outside" (Hall, The Beautiful Indifference 71). The short story is carefully structured, with the protagonist's new existence being carefully entangled with the mystery of the dead bees in the tiny London garden of the house where she is staying. The contrast between city and countryside is highlighted throughout the short story, and the city is identified as a place 
of refuge but not of belonging: "At night, in the garden, it occurs to you that it might have been your heart that left you as you reached the capital" (75). The event in the short story occurs at the very end of the narrative, which is also its climax. Again, there is a correlation between the main character and an animal, in this case, a fox:

Then you see it. There, in the corner of the hedge, is a disruption of colour, perhaps ten feet away from where you have been sleeping. You think at first you must be mistaken. But you are not. It's a fox [...] You watch it scan the air. It follows the heavy, resinous flight of a bee. It is a candid little hunter. It crouches for a moment, then springs up on its black legs. The jaw open and snap shut, and as it lands it shakes its red head furiously. (Hall, The Beautiful Indifference 85)

The fox suggests a poetic epiphany, an insight into the essential meaning of the character's existence, ultimately representing the difficulty of expressing in words, through language, one's reality. To come to terms with the fox's behaviour also means to come to terms with our behaviour as humans and to understand that we have much in common with animals. The fox has adapted to the city: "This one is unapologetic, going nowhere, as if it owns this city enclosure. It is as if the creature has been stoked up from the surroundings" (85). And just like the fox, the main character of "Bees" has also learned to survive in the city landscape.

"She Murdered Mortal He" offers us a quite different setting in Mozambique. Nevertheless, similar to the narrator of "Bees," who travels and whose new location feels unhomely, the protagonist in the short story is also in an unfamiliar setting. The faraway location is complemented by an oneiric atmosphere, with the action unfolding in the evening, reminding the reader of ghost stories. A couple go on a holiday to a distant place but break up. In order to escape from the argument, the female main character goes for a walk on the beach only to discover in panic that she is being followed by a creature:

After a while she turned and looked behind again. There was a white form a few hundred metres back down the beach [...] It was not him [...] A creature running towards her. A creature running towards her. She couldn't move, couldn't make a clear assessment [...] It was a dog. A big 
white dog was coming after her. (Hall, The Beautiful Indifference 124129)

The event unfolds as human and animal meet, potentiating the humananimal relationship in the narrative: "The dog looked down at her. Its eyes were dark, bright. [...] It looked at her. Its eyes very, very bright" (Hall, The Beautiful Indifference 130). It is as though both understand each other. The identification of humans with animals runs throughout Hall's short stories and imbues the narratives with a Kafkaesque tone. They eventually become part of the animal narrative tradition, growing closer to Franz Kafka's animal stories, as well as to twentieth- and twenty-firstcentury literature (that followed in their wake) depicting the interplay between humans and non-humans as is the case of Yann Martel's The Life of Pi (2001), or Zakes Mda's The Whale Caller (2005) (see Herman 2016). Indeed, Gilles Deleuze and Felix Guattari have pointed out the suppressed animality of humans present in Kafka's narratives:

Kafka's animals never refer to a mythology or to archetypes but correspond solely to new levels, zones of liberated intensities where contents free themselves from their forms as well as from their expression, from the signifier that formalized them. There is no longer anything but movements, vibrations, thresholds in a deserted matter: animals, mice, dogs, apes, cockroaches are distinguished only by this or that threshold. $(13)^{\mathrm{v}}$

The encounter with the animal in Hall's short story (as well as in others) allows the main character to come to terms with her nature, her supressed feelings, her fears and insecurities, realising that humans and animals are alike. The same dog that accompanies her along the beach to town is waiting for her on her return, but something has occurred that anticipates the end of the narrative: "[s]omething viscous and warm. When she shook her hands away they were tacky. She knew, before the thought really registered, that it was blood" (Hall, The Beautiful Indifference 140). At the very end of the narrative, the reference to "blood" reappears, and both reader and main character are left to figure out what might have happened. Nevertheless, the suspicion creeps in that the dog with whom the woman identifies is probably the dog that attacked her partner (and just like the 
attack on the farmer in "Butcher's Perfume," the attack in "She Murdered Mortal He" is not narrated in the story):

Você não está morta?

I just went for a walk, she said again. What's happening? I'm alright. $[\ldots]$

Ah, he said. OK. Your husband. He was looking around for you [...] He was... there was an attack, you see [...] No. Not a fight [...] Outside, in the dunes. But he was not conscious. There was a lot of blood. The wound is... (Hall, The Beautiful Indifference 145-146).

Finally, in "The Nightlong River," the event is the hunt, which must be understood as an occurrence persisting in time "by having different parts (or 'stages')" (Casati and Varzi np). Dolly Carter, the first-person narrator, hunts minks with her brothers in order to give a cape to her best friend Magda, who is terminally ill. The circumstance allows for considerations on life and death, humankind and nature:

The truth of death is a peculiar thing. For there was a fascination to these evenings that went past utility or sport. We were in the hinterlands, a wilding place, where the reign was ours entirely. We were the wolves. We were the lions. (Hall, The Beautiful Indifference 159).

The hunt triggers a feral disposition in Dolly and her brothers. In the midst of the wild, they chase their prey relentlessly: "We hunted [...] until [...] there was nowhere for the animals to hide or burrow. Of the ones we caught we raised the slack bodies up on forked sticks, dangled them from their necks, like the terrible flags of returning mercenaries" (Hall, The Beautiful Indifference 161).

In Hall's narratives, events are thus frequently linked to animals, and the latter are effectively a mirror of the violence inherent to the human condition, as exemplified in the short stories already discussed. Indeed, in "The Nightlong River," Dolly and her brothers behave as wild animals hunting minks. The protagonist of 'She Murdered Mortal He' identifies with the wild dog that (supposedly) attacked her partner. In "Bees" there is a correlation between the fox that survives in the city - a place of non-belonging - and the main character who travels to London and feels unhomely. In "The Beautiful Indifference," the protagonist 
wants to feel free and identifies with the straying horse in the narrative. In "Butcher's Perfume," the dying horse evinces how human and non-human destinies are closer than imagined. Furthermore, in "Mrs Fox," the opening story of her second collection, Madame Zero (2017), Sophia Garnett metamorphoses into a vixen right at the beginning of the story, while her husband looks incredulous and impotent:

What was all that about? Darling?

She turns her head and smiles. Something is wrong with her face. The bones have been re-carved [...] She stops, within calling distance, were he not struck dumb. She looks over her shoulder. Topaz eyes glinting. Scorched face. Vixen. (Hall, Madame Zero 8-9)

An element of anthropomorphism runs through the narrative, together with an oneiric, fairy-tale-like atmosphere. Eventually, it becomes a modern fable of women's empowerment. By transforming into a fox and embracing life in the wild, the main character transgresses the normative behavior associated with societal assumptions about women's identity, their domestic functions and the notion of motherhood as their ultimate role (see Letherby 1994), and rejects conventional married life. Ironically, by transforming into a vixen she retains all her 'foxy looks.' At the very beginning of the short story, the third-person narrator conveys the thoughts of the main character, Sophia's husband: "The shape of her eyes, almost Persian, though she is English. Her waist and hips in the blue skirt; he watches her move - to the sink, to the table, to the chair where she sits, slowly, with a woman's grace" (Hall, Madame Zero 1). Half-way through the short story, in the "first hours with his new wife" (12) there are interesting parallels: "She positions herself in the house, whenever she fancies [...]. The bend in her hind legs; the full, shapely thighs, similar, in a way, to a woman squatting [...]. Her smell is gamey; smoky, sexual" (13). In both moments of the narrative, Sophia is depicted in a domestic space and described roughly as a pet - when a woman, Sophia resembles an animal with eyes "almost Persian"; when transformed into an animal, her position is similar "to a woman squatting." Eventually, her husband realizes how he has objectified his wife: "He is angry and ashamed. That she could ever, even before this, be his pet" (18) and lets her go free: "He 
opens the utility door and leaves it standing open. [...] It doesn't take long. [...] She bolts, a long streak of russet down the lawn, between the plum trees, and up over the fence, the white tip flashing like an afterthought" (19). The idea of 'afterthought' evinces the husband's late awareness of his wife's wishes or goals and strengthens the reading of the short story as a modern fable of women's empowerment.

In direct contrast with the enclosed space of the domestic sphere, Sophia, the vixen, through 'an act of will' is now part of life in the wild: "After a while it dawns on him that she doesn't want to come back, that perhaps she did not want what she had. An act of will" (20). Throughout the short story, women's capacity for choice becomes central. Sophia's choice is transgressive insofar as she deviates from the traditional route of married life, taking control of her body and sexuality and breaking with societal norms and expectations, ultimately embodied in the character of the husband. The short story ends rather ambiguously; the husband seems to have understood Sophia's nature, but he still identifies her as his wife, the use of the pronoun suggesting the perpetuation of a certain social order. Finally, the rhetorical question at the end of the narrative - "how could life mean anything without his unbelonging wife?" - with the deliberate choice of adjective, casts a shadow over as to what the future holds (28).

Hall's modern fable "Mrs Fox" comprises an overt political commentary on gender and sexual politics at the beginning of the twentyfirst century. Throughout her short stories, Hall evinces a concern with feminist politics, with women's identity, with women's bodies and sexuality, with women in society and the politics of choice. As Young argues, "the smaller narrative space of the short story enables an element of ambivalence which is central to contemporary feminist approaches" (145). The event in "Mrs Fox" occurs at the beginning of the short story. The act of metamorphosing aligns the narrative with a long-standing tradition of animal tales, imbuing it with a Kafkaesque tone (see Deleuze and Guattari 2016). It also infuses the narrative with the ambivalence Young depicts as "central to contemporary feminist approaches" (145). The event becomes the "element of ambivalence" (145) which triggers thoughts on constraints and tensions linked with gendered politics as 
regards women's identity and sexuality, marriage and domesticity, as well as motherhood. Women writers' engagement with the genre of the short story has allowed for an innovative approach to both form and content, breaking away from normative models, experimenting with form while simultaneously deconstructing gender and cultural binary oppositions. All of these features may be found in "Mrs Fox," as well as in the short stories previously discussed. Hall's short stories introduce the reader to what the poet Kate Clanchy describes as 'vixen-shaped' stories: "Great short stories are the shape of themselves: image, voice and plot dovetailed to the chosen form. Hall's stories are vixen-shaped: urban and rural, feral and natural, female and stinky, beautiful and tough" (The Guardian).

The event in Hall's 'vixen-shaped' short stories is central to her innovative approach to both form and content. As mentioned previously, it does not necessarily concern an occurrence involving an animal. It may rather focus on the precariousness of life and an ethics of relational autonomy, the capacity of the protagonists to be authentic, to live their own life, surpassing cultural or social contingencies imposed externally upon them (see Mackenzie and Stoljar). In Madame Zero, for instance, three short stories, in particular, illustrate this idea. "Wilderness," "Goodnight nobody," and "Later, His Ghost" are distinct short stories in form and style. Together they constitute a tryptic on different ways in which the event may occur in Hall's short stories, always linked with the precariousness of human life and the notion of autonomy.

"Wilderness" is set in the southern Cape in South Africa. Becca, the protagonist, joins her partner Joe and his childhood friend Zachary in a walk across the Kaaimans river viaduct near the seaside town of Wilderness in the Garden Route region. The hike is representative of the protagonist's choices, becoming a synecdoche of her life. The walk proves to be the wrong choice, just as her moving from England to South Africa with Joe had been a mistake: "The country was as tense as a nail, there were rules about race and language she didn't understand, and Joe was either angry or stoned" (Hall, Madame Zero 71). She decides to cross the Kaaimans, despite having been warned about the bridge, and finds herself in distress: "All round and underneath the view rushed and wobbled. The atoms of things were going wrong. Her eyes were flooding" (80). The 
vertigo she experiences towards the middle of the viaduct, when facing nature's immensity all around her (the height, the wind, the view down below to the valley, the river's mouth, and the hillside), is the event triggering an existential crisis. Eventually, it sets in motion dreamlike childhood memories of Whitby in England, making her come to terms with her past: "It was all right to be sad when someone died, that's what her foster parents had told her, even someone you hadn't known. Like the young woman who'd left the baby on the cliffs, before she jumped" (82). It is at the very end of the narrative, after crossing the viaduct that the main character is able to make sense of life's precariousness: "How quickly death could pass over, and then it wasn't believable anymore" (83). Looking back at the viaduct, Becca finally remembers the lyrics of "Mr Sandman": "Mr Sandman, bring me a dream [...]" (84), but there is a lurking ambiguity as regards the fulfillment of the song since, as an autonomous human being, the protagonist is the product of her own choices.

"Goodnight Nobody" is a third-person narrative focused on Jem, an eleven-year-old child, who is also the main character of the short story. The narrative revolves around a tragic accident that occurs in Jem's neighbourhood: a newborn who dies after a dog's attack. Throughout the narrative, the reader is given access to Jem's life, thoughts and feelings, and witnesses the transition into maturity of the protagonist. It is a coming-of-age short story, in which the main character has to come to terms with death. Words become central to the child since their meaning is often difficult to grasp: "Mortuary. Mortuary. Sometimes words got stuck in her head, usually if they sounded a certain way - strong, important" (Hall, Madame Zero 123). In opposition to her attempt to understand complex words is her dislike for Goodnight Moon, her halfbrother Sav's favourite book. Indeed, the prevailing nonsense of the children's book is at odds with her attempt to make sense of her life: "Sav turned and looked up at her, frowning. He didn't understand, but neither did Jem. Who was nobody? [...] It was exactly the opposite of funny, and opposites always created problems. The opposite of married. The opposite of love. The opposite of alive" (134). The need to make sense of life's frailty leads the main character to the hospital mortuary, in which her 
mother Mumm-Ra works. The moment in which Jem stands outside the mortuary, sees the hearse, the unnamed coffin, and is hauled by the thought that her mother "might be holding the little dead baby, carefully" (145) is the very event in the short story. It is the moment the main character realizes that life and death are inseparable: "Her mother would never die, because she couldn't, though all of this, all this, would be taking its toll" (145). The event becomes therefore a moment of revelation about how circumstances, experiences and the environment one lives in shape life.

"Later, His Ghost" is a cli-fi dystopic short story set in a postapocalyptic landscape. The narrative takes place in an imaginary future, in a world ravaged by violent windstorms. It is Christmas and the protagonist goes out into the tempest to find the remaining pages of Shakespeare's The Tempest. It is his surprise gift to Helene, who had been an English teacher, and who was now expecting a child and living with him in a lonely barn: "Good things had to be held onto, and remembered, and celebrated. That was why he had to get the pages for Helene and why they would try to have a nice Christmas" ("Later" 114). The event is his encounter with the "rows and rows of hardbacks," "the collection of Shakespeares" (118) and the play he was looking for. Ambiguity creeps in towards the end of the narrative since the protagonist is compared to a demon, reminding the reader of Caliban, half-human, half-monster: "He looked like some kind of demon. Maybe that's what he was, maybe that's what he'd become" (119). The adversative conjunction 'but' reinforces the idea that despite the doomful setting there are remnants of humanity in him: "But he felt human; he remembered feeling human. [...] And he liked Christmas" (119). In this open-ended narrative, the reader may be reminded in the last sentence of the short story that there is an ongoing tempest outside the safe haven the main character has just found - "Snow was flying past" (119) - but it is Christmas and Helene is pregnant, which suggests new beginnings and possibilities.

The event is therefore crucial in Hall's short stories. An occurrence or a series of occurrences may take place at any given moment of the narrative: at the very beginning, as is the case with "Mrs Fox" and her metamorphosis into a vixen; towards the middle of the short story, as it 
becomes evident in "The Beautiful Indifference"; or at the very end, as in "Bees." It may or may not involve an encounter with an animal. Except for "The Nightlong River," the short stories discussed from The Beautiful Indifference are all examples of the first ("Butcher's Perfume," "The Beautiful Indifference," "Bees," "She Murdered Mortal He"). But not all short stories revolve around an event triggered by an encounter with an animal. Except for "Mrs Fox," the short stories examined from the collection Madame Zero suggest the event is also the encounter with the self, underlining how precarious life is, and how, as autonomous human beings, the choices we make matter, as becomes evident in the tryptic of stories discussed ("Wilderness," "Goodnight nobody," and "Later, His Ghost"). Despite its apocalyptic tone or precisely because of it, the last short story, "Later, His Ghost," suggests that regaining or securing autonomous control over life, in particular after tragic events, is also to learn and value caring for other people. Autonomy is therefore relational, as is clearly shown by the protagonist of "Later, His Ghost," who risks his life to offer The Tempest to Helene. The short story becomes a metatext, depicting the power of words and the redeeming power of literature even in an apocalyptic scenery. Indeed, together with "Later, His Ghost," "Sudden Traveler" epitomizes the move in Hall's short fiction from an ethics of autonomy towards an ethics of care (see Mackenzie and Stoljar).

\section{Conclusion: "Sudden Traveler"}

"Sudden Traveler" is Hall's most recent short story to be shortlisted for the BBC National Short Story Award. It gave the name to Hall's third collection of short stories, Sudden Traveler, in 2019. As Stig Abell, the editor of the Times Literary Supplement, mentions in the introduction written to the volume in which the short story first appeared: "'Sudden Traveller' by Sarah Hall is about grief and life. It tells the story of a woman nursing her child at the same time as she mourns the death of her mother" (vi). The opening of the short story immediately directs the reader towards familiar ground, the main themes pursued by Hall in her fiction: life versus death, as well as nature versus human. The short story stresses the correlation between humankind and nature, with the latter's 
brutal disposition the only means by which mourning can take place. Nature is depicted as weeping as preparations are made for the protagonist's mother to be buried:

You breastfeed the baby in the car, while your father and brother work in the cemetery. They are clearing the drains of leaves and silt, so your mother can be buried. November storms have brought more rain than the valley has ever seen $[\ldots]$ The river has become a lake; it has breached the banks, spanned the valley's sides. And still the uplands weep. (Hall, Sudden Traveler 97)

The structure of "Sudden Traveler" oscillates between the present moment, flashbacks and flashforwards. The memories of the dying mother and her reaction to the grandson are central in the narrative: "Your son's name was the only word she could say properly, though she was trying and trying to talk, her voice hoarse, making no sense" (100). Furthermore, the flashforwards are attempts at predicting the unpredictable: "Later, you will remember this. You will remember it while standing on board a ship, [...] as you make the crossing [...] from suffering to happiness" (115). These rhetorical strategies give the short story its form and direction, attempting to assimilate in its shape the complexity of the subject matter addressed.

The experience of becoming a mother while simultaneously losing the maternal figure prompts the main character to ask philosophical questions linked to the very meaning of life and death: "The terror of being taken, ahead, into sheer darkness. What is coming? Not just this lesson of a dying mother" (Hall, Sudden Traveler 108-109, my emphasis). Faced with the duty of bearing her mother's coffin to the church and the cemetery, she hesitates: "Will you remain upright, sure-footed? Will you break down under grief?" (109). Eventually, the protagonist comes to terms with loss and concludes "We are, all of us, sudden travelers in the world, blind, passing each other, reaching out, missing, sometimes taking hold" (110). The title's reference to a sudden traveler is therefore a reference to the main character, her mother, her child, as well as her father, her brother and 'all of us,' even the reader. Hall's short story - like much of her (short) fiction - investigates an ethics of care, dwelling upon 
the connection between care and responsibility to others. Virginia Held defines the potential of this alternative approach:

It has the potential of being based on the truly universal experience of care. Every human being has been cared for as a child or would not be alive. Understanding the values involved in care, and how its standards reject violence and domination, are possible with the ethics of care. (3)

Hall's short story demonstrates the profound nature of relationships between individuals. It attests to the immense task of caring for children and dependent persons in sickness and old age, as is the case of the main character's mother. However, although the narrative follows a female point of view, and the main character is undoubtedly depicted as a carer from the first sentence of the short story, men are equally depicted as being involved in and committed to the act of care:

All of you, over the last week, have been driving to and from the hospital, dozing in the chairs, bringing supplies. Only your father remained in full attendance, requesting clothes and his medication [...] Tell me when, your brother had said to your dad the last night at the hospital, as he was leaving, tell me to come and I'll get there in time. (Hall, Sudden Traveler 103)

Against impotence in the face of death, stories are depicted as healing. Stories are gateways into the world, assisting us, guiding us, comforting us. They tell us about human experience, they allow us to come to terms with the past and imagine future possibilities, redeeming our human condition and emphasizing the central role of literature in life:

Stories are the currency of past lives. Families, lovers, enemies, friends. You do not understand yet, who you will lose, who you will become, who will arrive. [...] But, sooner than you think, after this flood, after the darkness, the loss, the loneliness, someone is going to take your hand and tell a story about the death of his grandfather. [...] He carried it too, this teller, this future traveler. The story will feel so familiar to you. You will begin to understand that those who suffer, suffer the same. In this condition, we are never alone. (Hall, Sudden Traveler 109-110)

The narrative comes full circle. The burial will take place and the main character will carry her mother's coffin. The event coincides with the 
denouement of the narrative: the protagonist complying with her duty as a daughter and as a human being. Nature watches over and is a reminder of both the transience and ephemerality of human existence: "you will carry her, all the way, you will carry her, steadily, [...] and the rain will hold off, and the mountains will neither pity nor forgive you" (Hall, Sudden Traveler 116-117). Life will continue relentlessly as the short story coming to an end demonstrates so clearly.

To read Hall's narratives is to share human experiences, understanding holistically the self and its connection with nature and the wilderness. The empathy of the main (female) characters towards both animals and the landscape/ nature that surrounds them mirrors humankind's ongoing attempt to bridge the gap between society and nature. They are immanent and particular, but, in dealing with life and death, they are also universal and atemporal.

\section{Notes:}

\footnotetext{
${ }^{\mathrm{i}}$ In the same edited volume, John Beever discusses the importance of the Save Our Short Story Campaign, backed by the Arts Council in the UK, for the revival of interest in the short story (Cox 11-25). Cox also refers to the role of international conferences - such as the ones held by the Society of the Short Story - in promoting short story theory and bringing critics and practitioners together (24). See also May (24).

ii Even a piece such as 'Cumbrian Fell Pony' from the section "Essays \& Memoir" in Granta 142: Animalia (The Online Edition, 20 February 2018) is likely to be read as a short story but from a personal point of view.

iii Madame Zero actually won the 2018 Edge Hill Readers' Choice Award, selected by twenty Edge Hill Creative Writing students.

iv The short story "Sudden Traveler" gives its name to Hall's third collection of short stories, Sudden Traveler (2019).

${ }^{v}$ In conversation with Kafka's narratives, other philosophers have also discussed the proximity between man and animal in literature, for example Walter

Benjamin ("Franz Kafka: On the Tenth Anniversary of His Death" 1934) and

Theodor W. Adorno and Max Horkheimer (Dialectic of Enlightenment 1944).
}

\section{Works Cited}

Abell, Stig. The BBC National Short Story Award 2018. Mytholmroyd: Comma Press, 2018. 
Adorno, Theodor W., and Max Horkheimer. Dialectic of Enlightenment. 1944. London and New York: Verso, 1995.

Andrew, Kerry, Sarah Hall, Kiare Ladner, Ingrid Persaud and Nell Stevens. The BBC National Short Story Award 2018. Manchester: Comma P, 2018.

Baker, Sam. "The Irresistible Rise of the Short Story." The Telegraph 18 May 2014. Web. 1 June 2019.

Benjamin, W. "Franz Kafka: On the Tenth Anniversary of His Death." 1934. Selected Writings 2, 1927-1934. Ed. M. W. Jennings, H. Eiland, and G. Smith. Trans. R. Livingstone et al. Cambridge, MA: Belknap, 1999. 794-818.

Bourdieu, Pierre. The Field of Cultural Production: Essays on Art and Literature Ed. Randal Johnson. Cambridge, UK: Polity P, 1993.

Casati, Roberto, and Achille Varzi "Events." The Stanford Encyclopedia of Philosophy (Winter Edition). Ed. Edward N. Zalta. 2015. Web. 22 July 2019.

Clanchy, Kate. "Madame Zero by Sarah Hall Review - Exceptional Short Stories." The Guardian 7 July 2017. Web. 1 June 2019.

Cox, Ailsa, ed. The Short Story. Newcastle upon Tyne: Cambridge Scholars, 2008.

Deleuze, Gilles, and Felix Guattari. Kafka: Toward a Minor Literature. 1986. Trans. Dana Polan. Minneapolis: U of Minnesota P, 2016.

Hall, Sarah. The Beautiful Indifference. London: Faber, 2011.

---. Madame Zero. London: Faber, 2017.

---. Sudden Traveler. London: Faber, 2019.

Hanson, Clare, ed. Re-Reading the Short Story. London: Palgrave Macmillan, 1989.

Held, Virginia. The Ethics of Care: Personal, Political and Global. Oxford: Oxford UP, 2006.

Hensher, Philip, ed. The Penguin Book of the Contemporary British Short Story. London: Penguin, 2018.

Herman, David, ed. Creatural Fictions. Human-Animal Relationships in Twentieth- and Twenty-First-Century Literature. Houndmills: Palgrave Macmillan, 2016.

Letherby, Gayle. "“Mother or Not, Mother or What? Problems of Definition and Identity”." Women's Studies International Forum 17.5 (1994): 525-532.

Mackenzie, Catriona, and Natalie Stoljar, eds. Relational Autonomy: Feminist Perspectives on Autonomy, Agency and the Social Self. Oxford: Oxford UP, 2000.

May, Charles E. "Why Short Stories Are Essential and Why They Are So Seldom Read." The Art of Brevity: Excursions in Short Fiction Theory and Analysis. Ed. Per Winther, Jakob Lothe and Hans H. Skei. Columbia: U of South Carolina P, 2004. 14-25.

Oxford English Dictionary Online. Oxford University Press. Web 1 June 2019. Young, Emma. Contemporary Feminism and Women's Short Stories. Edinburgh: Edinburgh UP, 2018. 